University of Nebraska - Lincoln

DigitalCommons@University of Nebraska - Lincoln

November 1998

\title{
Selenocysteine-Containing Proteins in Mammals
}

Vadim N. Gladyshev

University of Nebraska-Lincoln, vgladyshev@rics.bwh.harvard.edu

Dolph L. Hatfield

Section on the Molecular Biology of Selenium, Basic Research Laboratory, Division of Basic Sciences, National Cancer Institute, National Institutes of Health, Bethesda, Md.

Follow this and additional works at: https://digitalcommons.unl.edu/biochemgladyshev

Part of the Biochemistry, Biophysics, and Structural Biology Commons

Gladyshev, Vadim N. and Hatfield, Dolph L., "Selenocysteine-Containing Proteins in Mammals" (1998). Vadim Gladyshev Publications. 77.

https://digitalcommons.unl.edu/biochemgladyshev/77

This Article is brought to you for free and open access by the Biochemistry, Department of at DigitalCommons@University of Nebraska - Lincoln. It has been accepted for inclusion in Vadim Gladyshev Publications by an authorized administrator of DigitalCommons@University of Nebraska - Lincoln. 


\title{
Review
}

\section{Selenocysteine-Containing Proteins in Mammals}

\author{
Vadim N. Gladysheva Dolph L. Hatfield ${ }^{b}$ \\ aDepartment of Biochemistry, University of Nebraska, Lincoln, Nebr., and bection on the Molecular Biology of \\ Selenium, Basic Research Laboratory, Division of Basic Sciences, National Cancer Institute, National Institutes \\ of Health, Bethesda, Md., USA
}

\section{Key Words}

Selenocysteine - Selenoproteins - Selenoenzymes . Glutathione peroxidase $\cdot$ lodothyronine deiodinase . Thioredoxin reductase - Selenoprotein P. Codon UGA

\begin{abstract}
Since the recent discovery of selenocysteine as the 21st amino acid in protein, the field of selenium biology has rapidly expanded. Twelve mammalian selenoproteins have been characterized to date and each contains selenocysteine that is incorporated in response to specific UGA code words. These selenoproteins have different cellular functions, but in those selenoproteins for which the function is known, selenocysteine is located at the active center. The presence of selenocysteine at critical sites in naturally occurring selenoproteins provides an explanation for the important role of selenium in human health and development. This review describes known mammalian selenoproteins and discusses recent developments and future directions in the selenium field.
\end{abstract}

Selenium is an essential element for many forms of life. It is a component of naturally occurring selenium-containing proteins and transfer RNAs. In mammals, selenium is covalently bound in all selenoproteins described to date as the amino acid selenocysteine (Sec) [48]. In bacterial proteins, selenium also occurs as Sec [49], but in addition this element is present in some selenoproteins as a dissociable, catalytically essential cofactor $[26,27,36$, 37]. Selenium-containing tRNAs have been detected in mammals [19] and bacteria [20], but only bacterial seleno-tRNAs have been characterized [98]. The present review will discuss known selenoproteins in mammals and future developments in the selenium field. Additional information on the biology of selenium may be found in other recent reviews $[14,46,48,51,62,63,66,86]$.

\section{The Past: The 21st Amino Acid in Protein}

The discovery that the code word UGA has a dual function in the 'almost' universal genetic code [46] marks the first addition to the code [64] since it was deciphered $[57,75]$ and reported to be universal in the mid $1960 \mathrm{~s}$ [70]. UGA serves as both a codon for termination of protein synthesis and as a codon for Sec. In this sense, UGA is analogous to AUG, which functions as both a codon for initiation of protein synthesis and a codon for methionine at internal positions of proteins. The role of UGA as a codon for Sec has been known for about 10 years [64]. However, the fact that Sec is the 21st naturally occurring amino acid in protein is completely accepted as Sec has its own tRNA, code word, translation factors and other com-

\begin{tabular}{ll}
\hline KARGER & (1999 National Science Council, ROC \\
Fax +41613061234 & S. Karger AG, Basel \\
$\begin{array}{l}\text { E-Mail karget@karger.ch } \\
\text { www, karger.com }\end{array}$ & $\begin{array}{l}\text { Accessible online at: } \\
\text { bttp:/BioMedNet.com/karger }\end{array}$
\end{tabular}

Dr. Vadim N. Gladyshev

Department of Biochemistry, University of Nebraska

Lincoln, NE 68588 (USA)

Tel. +14024724948 , Fax +14024727842

E-Mail vng@uninfo2.unl.edu 
ponents involved in the protein translation machinery $[14,48]$. The presence of a Sec insertion sequence (SECIS) element downstream of the UGA codon that codes for this amino acid is necessary for its recognition as a signal for Sec insertion [66]. Mammalian SECIS elements are stem-loop structures located in the 3'-untranslated region of selenoprotein mRNAs [66], while the corresponding stem-loop structures in bacterial selenoproteins are immediately downstream of the UGA Sec codon [14].

An interesting feature of Sec biosynthesis is that this amino acid is synthesized on its tRNA. There are many common steps in Sec biosynthesis in mammalian and bacterial systems, but the biosynthesis of this amino acid has only been completely established in prokaryotes [14]. Sec tRNA is first aminoacylated with serine, the serine moiety is in turn modified to an aminoacrylyl intermediate on TRNA in bacterial systems by Sec synthase and then the intermediate serves as the acceptor for activated selenium. The selenium donor is selenophosphate which is synthesized by selenophosphate synthetase [86]. Many of these steps are apparently very similar in mammals with the exception that the intermediate in Sec biosynthesis has not been identified and may actually be phosphoseryl-tRNA $[47,48]$. In any case, this unique pathway is highly specific for selenium as sulfur shares many chemical and physical properties with selenium, but sulfur cannot replace selenium in Sec biosynthesis. On the other hand, selenium can readily substitute for sulfur in sulfur pathways and be incorporated nonspecifically into proteins in the form of selenomethionine (replacing methionine), Sec (replacing cysteine) and selenium analogs of sulfur cofactors [reviewed in 48].

\section{The Present:}

\section{Selenoproteins, an Even Dozen Thus Far}

Twelve mammalian selenoproteins have been described to date which are shown in table 1 . They represent various protein families. Sec is present at the active centers of the characterized selenoenzymes which are the glutathione peroxidases, the iodothyronine deiodinases, thioredoxin reductase and selenophosphate synthetase. Although Sec occurs infrequently in protein compared to other amino acids, its presence at a critical site in these enzymes suggests that selenium is important for a variety of biological processes and for human health [63].

A common feature among mammalian selenoproteins is that they appear to regulate and/or be regulated by intraand/or extracellular redox processes. Nature may have tak- en advantage of utilizing Sec at critical sites in certain enzymes due to the unique redox properties of selenium [16]. Although Sec is structurally similar to cysteine, selenium is a better nucleophile than sulfur and selenocysteines are ionized at physiological $\mathrm{pH}$, while cysteines typically are protonated $[48,86]$. The biological function of several selenoproteins, including selenoprotein $P$, selenoprotein $\mathrm{W}$ and the $15-\mathrm{kd}$ selenoprotein, remains unknown. These proteins, however, contain putative Sec redox-active centers and it is therefore tempting to speculate that these centers serve a redox-dependent function.

\section{The Glutathione Peroxidase Family}

The glutathione peroxidase selenoenzyme family contains four members, GPX1, GPX2, GPX3 and GPX4. GPX1 is also called classical or cytosolic glutathione peroxidase, GPX2, gastrointestinal glutathione peroxidase, GPX3, plasma glutathione peroxidase, and GPX4, phospholipid hydroperoxide glutathione peroxidase. GPX1, GPX2, GPX3 and GPX4 have also been abbreviated as cGPX, GPX-GI, pGPX and PHGPX, respectively. Glutathione peroxidases are homologous enzymes, which share several common features such as they catalyze glutathione-dependent degradation of hydroperoxides and utilize Sec as a critical component of the enzyme active center. However, each member of this class of selenoenzymes has several distinct characteristics and our current knowledge of each is summarized below. Additional information on the glutathione peroxidase family of enzymes may be found in the following reviews $[2,22,48$, $88,93,94]$.

(1) Glutathione Peroxidase 1 (GPX1 or cGPX). GPX1 is one of the most thoroughly studied and best-characterized selenoproteins. It catalyzes glutathione-dependent reduction of hydrogen peroxide and various organic hydroperoxides. The enzyme is a homotetramer of $-22 \mathrm{kd}$ subunits and it is located in the cytosol. The genes for mouse GPX1 and Escherichia coli formate dehydrogenase $\mathrm{H}$ were the first selenoprotein genes to be sequenced, which revealed that Sec is encoded by TGA $[18,103]$. Bovine erythrocyte GPX1 has been crystallized and its three-dimensional structure determined [29]. Although GPX1 is considered, together with catalase and superoxide dismutase, as a major antioxidant enzyme, its role as an essential antioxidant has been questioned. Indeed, dramatic losses in GPX1 activity and expression level occur in selenium-deficient animals [89] without an apparent effect on cellular metabolism. Such observations led investigators to propose that GPX1 may serve as a selenium storage or selenium buffer protein [88]. In addition, when 
Table 1. Mammalian selenocysteine-containing proteins

\begin{tabular}{|c|c|c|c|c|}
\hline \multicolumn{2}{|c|}{ Selenoprotein } & \multirow{2}{*}{$\begin{array}{l}\text { Function } \\
\text { Glutathione-dependent } \\
\text { hydroperoxide removal }\end{array}$} & \multirow{2}{*}{$\frac{\text { Expression }}{\text { Ubiquitous }}$} & \multirow{2}{*}{$\begin{array}{l}\text { Chromosomal } \\
\text { locallization } \\
\text { h } 3 \mathrm{q} 11-13.1 \\
\text { and/or } 3 \mathrm{p} 21.3 \\
\mathrm{~m} \text { chr. } 9\end{array}$} \\
\hline 1 & $\begin{array}{l}\text { Glutathione peroxidase } 1 \\
\text { (GPXI or cGPX) }\end{array}$ & & & \\
\hline 2 & $\begin{array}{l}\text { Glutathione peroxidase } 2 \\
\text { (GPX2 or GPX-GI) }\end{array}$ & $\begin{array}{l}\text { Glutathione-dependent } \\
\text { hydroperoxide removal }\end{array}$ & Gastrointestinal tract & $\begin{array}{l}\text { h } 14 q 24.1 \\
\text { m chr. } 12\end{array}$ \\
\hline 3 & $\begin{array}{l}\text { Glutathione peroxidase } 3 \\
\text { (GPX3 or pGPX) }\end{array}$ & $\begin{array}{l}\text { Antioxidant } \\
\text { (hydroperoxide removal) }\end{array}$ & Plasma & $\begin{array}{l}\text { h chr. } 5 \\
\text { m chr. } 11\end{array}$ \\
\hline 4 & $\begin{array}{l}\text { Phospholipid hydroperoxide } \\
\text { glutathione peroxidase } \\
\text { (GPX4 or PHGPX) }\end{array}$ & $\begin{array}{l}\text { Phospholipid hydroperoxide } \\
\text { removal }\end{array}$ & Ubiquitous & h $19 \mathrm{p} 13.3$ \\
\hline 6 & Thyroid hormone deiodinase 2 (D2) & Conversion of $T_{4}$ to $T_{3}$ & $\begin{array}{l}\text { Pituitary and thyroid glands, } \\
\text { placenta, heart and skeletal muscles, } \\
\text { central nervous system, brown fat }\end{array}$ & h $14 q 24.3$ \\
\hline 7 & Thyroid hormone deiodinase 3 (D3) & Inactivation of $T_{3}$ and $T_{4}$ & Placenta, central nervous system, skin & $\begin{array}{l}\mathrm{h} 14 \mathrm{q} 32 \\
\mathrm{~m} 12 \mathrm{~F} 1\end{array}$ \\
\hline 8 & Thioredoxin reductase (TR1) & $\begin{array}{l}\text { NADPH-dependent } \\
\text { reduction of thioredoxin }\end{array}$ & Ubiquitous & h $12 \mathrm{q} 23-\mathrm{q} 24.1$ \\
\hline 9 & Selenophosphate synthetase 2 (SPS2) & Synthesis of selenophosphate & Ubiquitous & $\mathrm{m}$ chr. 7 \\
\hline
\end{tabular}

Chromosomal localization is shown for human $(\mathrm{h})$ and mouse $(\mathrm{m})$ selenoprotein genes.

mice lacking the GPX1 gene were generated, no phenotypic changes were observed in these knockout mice, even under hyperoxia conditions [54]. However, recent findings of the essential role of GPX1 in protection of mice from viral-induced myocarditis suggest that this enzyme may be important in rescuing cells from environmental stress [4], while its function under normal conditions may be compensated for by other cellular components.

Supplementation of the diet with selenium has been shown to reduce the risk of prostate, colon and lung cancers [23], and chemopreventive properties of this element have been associated with GPX1. Expression of this enzyme is often altered in malignant cells relative to controls [30]. Interestingly, GPX1 exhibits contrasting patterns of regulation with another antioxidant selenoenzyme, thioredoxin reductase, in several tested cancer systems [41]. Further research is necessary to determine which selenoprotein(s) are indeed responsible for chemopreventive properties of selenium.

(2) Glutathione Peroxidase 2 (GPX2 or GPX-GI). GPX2, like GPX1, is a tetramer consisting of identical $22-\mathrm{kd}$ subunits and occurs in the cytosol. However, in contrast to GPX1, which is expressed in every cell type tested, GPX 2 is mainly expressed in the epithelium of the 
gastrointestinal tract [22]. In this organ, GPX2 activity accounts for about $50 \%$ of the total selenium-dependent glutathione peroxidase activity [31].

(3) Glutathione Peroxidase 3 ( GPX3 or $p G P X$ ). GPX3 differs from other glutathione peroxidases in that it is a glycoprotein and it is the only extracellular selenium-containing glutathione peroxidase. GPX3 is able to detoxify hydroperoxides in the presence of glutathione. However, since the levels of glutathione in plasma are extremely low, an alternative reducing substrate has been sought. Indeed, it was found that thioredoxin, thioredoxin reductase or glutaredoxin are better electron donors than glutathione for GPX3 under physiological conditions [11]. These findings are reinforced by the lack of conservation of the glutathione-binding site in this glutathione peroxidase [94]. The crystal structure at $2.9 \AA$ has been recently reported for GPX3 [81] providing an explanation for differences in substrate specificity and catalytic activities of plasma and intracellular glutathione peroxidases.

(4) Glutathione Peroxidase 4 (GPX4 or PHGPX). GPX4 is different from other selenium-dependent glutathione peroxidases in that it is capable of reducing phospholipid hydroperoxides. GPX4 is an $\sim 19-\mathrm{kd}$ monomeric enzyme and it occurs in both a soluble and a membrane-bound form. The subcellular localization of GPX4 is controlled by alternative transcription and translation sites [78]. Under conditions of limiting selenium, selenium is preferentially incorporated into GPX4 relative to GPX1. GPX4 is ubiquitously expressed and is one of the most abundant selenoproteins in mammals (the other most abundant intracellular selenoproteins are GPX1, thioredoxin reductase (TR) and the 15-kd selenoprotein). The dramatic elevation of GPX4 expression in testis after puberty suggests that this selenoenzyme may have a role in the male reproductive system [69]. Other selenoproteins may also be involved in mediating an essential role of selenium in spermatogenesis, particularly testis-specific selenoproteins [87].

\section{The Iodothyronine Deiodinase Family}

The iodothyronine deiodinases are a family of three oxidoreductases that regulate the activity of thyroxine by catalyzing removal of iodine from the inner (5-iodine) or outer (5'-iodine) ring of this hormone. Thyroxine is secreted by the thyroid gland and the deiodinases, designated type 1, type 2 and type 3 deiodinase or D1, D2 and $\mathrm{D} 3$, are primarily located in mammalian tissues peripherally to the thyroid. Although D1, D2 and D3 have different roles in the activation and inactivation of thyroxine, these deiodinases share several common features. All three are selenoenzymes containing the Sec residue in a highly homologous sequence that is located in the midregion of each protein. Sec occurs at the enzymes' active center and is most likely involved in the transfer of iodine. Each deiodinase is an integral membrane protein and thus contains, as would be expected, a hydrophobic sequence in the $\mathrm{N}$-terminal portion of the enzyme. There are several distinct features of D1, D2 and D3 which are discussed below. It should also be noted that an excellent review on the deiodinase family has recently been published [62] and a more detailed account of the substrates, substrate specificities and primary structures of each deiodinase may be found in this review.

(5) Type 1 Deiodinase (D1). D1 is a $29-\mathrm{kd}$ selenoprotein that is capable of deiodinating both the inner and outer ring of the prohormone, $T_{4}$. Thus, $D 1$ can convert $T_{4}$ to the active hormone, $T_{3}$, as well as inactivate both $T_{4}$ and $T_{3}$. Its role is to provide $T_{3}$ to the plasma and to inactivate $T_{4}$ and $T_{3}$. It is located in the thyroid, liver, kidney and central nervous system and is a thyroid-responsive selenoenzyme.

D1 occupies a unique historical position in the elucidation of selenoprotein biosynthesis in mammals. The location of the SECIS element in mammalian selenoprotein mRNA and the role of the SECIS element in determining that a UGA codon designates $S e c$ instead of termination was first demonstrated with D1 mRNA $[9,10]$.

(6) Type 2 Deiodinase (D2). D2 is a $30.5-\mathrm{kd}$ selenoprotein that catalyzes the conversion of $\mathrm{T}_{4}$ to $\mathrm{T}_{3}$. The $\mathrm{Km}$ of $\mathrm{D} 2$ for $\mathrm{T}_{4}$ is three orders of magnitude lower than that of $\mathrm{D} 1$ for $\mathrm{T}_{4}$. This selenoenzyme is essential for providing a source of $T_{3}$-receptor-bound $T_{3}$ in the brain and pituitary gland. D2 activity may be regulated both pre- and posttranslationally by $\mathrm{T}_{4}$ [see 24 and references therein]. Interestingly, a second TGA codon is encoded in the gene for rat and human D2 eight codons from the termination codon that may signal Sec insertion into protein or termination of protein synthesis during transient expression $[24,85]$. D2 is expressed in the pituitary gland, the central nervous system, placenta and brown fat of humans and rats and in the thyroid gland and skeletal and heart muscle of humans, but not rats.

(7) Type 3 Deiodinase (D3). D3 is a $31.5-\mathrm{kd}$ selenoprotein that inactivates $T_{3}$ and $T_{4}$ by catalyzing the removal of iodine from the inner ring of either substrate. D3, like D1, is a thyroid-responsive selenoenzyme and it plays the major role in inactivating $T_{3}$ or $T_{4}$. It occurs in placenta, the central nervous system and skin. D3 is expressed in highest levels in placenta and functions to impair access of $T_{3}$ and $T_{4}$ to the fetus. 


\section{(8) Thioredoxin Reductase (TR)}

Mammalian TR was first characterized in late 1970s [56], but it was not until 1996 that this enzyme was recognized as a selenoprotein $[38,91]$. Although most selenoproteins contain $\mathrm{Sec}$ in the $\mathrm{N}$-terminal portion or in the middle of the protein, TR contains $\mathrm{Sec}$ as a C-terminal penultimate residue $[35,38,102]$, which is essential for enzyme activity $[1,42,52]$. TR is a homodimer consisting of two identical 55-kd subunits, each containing a flavin adenine dinucleotide cofactor. The major function of TR is to catalyze NADPH-dependent reduction of thioredoxin in the cytosol [83]. In addition, TR has been implicated in a variety of processes, including the reductions of glutathione peroxidase [11], disulfide isomerase (and related enzymes) [67, 68], dehydroascorbate [73], ascorbyl-free radical [74], selenite, selenodiglutathione [13], hydroperoxides [12] and other proteins and compounds. The broad substrate specificity of TR has been attributed to the presence of $\mathrm{Sec}$ in the enzyme. However, the puzzling location of Sec in a conserved C-terminal Gly-Cys-SecGly tetrapeptide cannot be explained easily, since other members of the pyridine nucleotide-disulfide oxidoreductase family, such as glutathione reductase and lipoamide dehydrogenase, lack the $\mathrm{C}$-terminal Sec-containing extension [38]. Relative to these other enzymes, TR has three orders of magnitude higher reactivity to several inhibitory gold, quinone and alkylating compounds $[1,28,44,60$, $71,72,76,95]$. The high reactivity of TR to these compounds has also been attributed to $\mathrm{Sec}$ in the enzyme. The purified reduced TR can be inactivated by oxygen, while elevated levels of oxygen in the growth medium resulted in a lower specific activity of TR. These oxygen-dependent processes have been associated with the loss of selenium from the enzyme [42].

TR is often overexpressed in malignant tissues $[34,38$, 41] and it has oncoprotein-like properties [59]. Products of oncogenes may stimulate cell proliferation and also sensitize cells to apoptosis [32]. A role of TR and its substrate thioredoxin in cell proliferation $[3,33,34,90]$ and apoptosis $[25,55,84]$ has been reported. In addition, TR and thioredoxin are involved in redox regulation of cell signaling [87]. TR occurs in a variety of isoform and isoenzyme types $[38,42,61,82,87,91]$. We recently discovered and characterized two new mammalian thioredoxin reductases TR2 and TR 3 that contain a TGAencoded Sec residue [87]. TR2 is preferentially expressed in testis, while TR 3 contains a mitochondrial targeting signal and is expressed in various cell types [87].

\section{(9) Selenophosphate Synthetase 2 (SPS2)}

SPS2 is a recently discovered $\sim 50-\mathrm{kd}$ selenoenzyme [45]. It catalyzes activation of selenium in an ATP-dependent manner. The product, which is selenophosphate, donates selenium to the intermediate in the biosynthesis of Sec on tRNA. The natural selenoenzyme has not been isolated, which precluded its detailed characterization, but the selenide-dependent activity has been demonstrated for the overexpressed cysteine-for-Sec mutant of SPS2 [58]. SPS2 is homologous to mammalian selenophosphate synthetase 1 (SPS1), with the latter replacing the putative active center Sec with threonine [65]. Which of these two selenophosphate synthetases is the major protein involved in selenoprotein synthesis remains to be determined. Selenophosphate synthetase genes have been found in bacteria, archaea, Drosophila melanogaster and Caenorhabditis elegans. These genes encode either Seccontaining or homologous cysteine-containing enzymes. The finding of Sec in mammalian SPS2 is important in view of the possible autoregulation mechanism of selenoprotein synthesis, i.e., SPS2 is possibly involved in its own biosynthesis [45].

\section{(10) Selenoprotein P (Sel P)}

Sel $\mathrm{P}$ ( $\mathrm{P}$ designates plasma) is a 57-kd glycoprotein and is the major selenoprotein in the plasma of mammals [51]. It contains 9-12 Sec residues depending on the organism in which it occurs and is the only known selenoprotein that contains more than one Sec residue [80]. All Sec residues in this selenoprotein are coded by UGA. The efficiency of Sec incorporation at each UGA codon in Sel $\mathrm{P}$ mRNA appears to be different which results in multiple product forms [21] that arise from termination at different UGA codons [53]. In particular, the second in-frame UGA codon dictates significant termination giving rise to a selenoprotein product that may have a separate function [53]. Sel P contains two types of SECIS elements in the 3 -untranslated region of its mRNA suggesting that both are required for $\mathrm{Sec}$ insertion in response to multiple and different UGA codons [50]. The protein is rapidly expressed following supplementation of selenium-deficient animals with selenium. It has been suggested that Sel $\mathrm{P}$ serves as an antioxidant [17] or selenium storage (or transport) protein. Further studies are required to establish the function of this interesting selenoprotein.

\section{(11) Selenoprotein W (SelW)}

SelW is a $\sim 8$-kd intracellular protein of unknown function [96]. A single Sec residue is present in this protein in an N-terminal putative active center redox motif 
Cys-Gly-Ala-Sec-Gly [97], suggesting the possible involvement of the protein in a redox-related process. The isolated protein may occur in the glutathionylated form [8], which is consistent with a putative redox role for SelW. The protein is expressed in many tissues and in increased levels in muscle and brain. SelW expression, as well as expression of most other selenoproteins are regulated by selenium [101], i.e., selenium elevates selenoprotein expression.

\section{(12) 15-kd Selenoprotein}

The $15-\mathrm{kd}$ protein is the most recently discovered selenoprotein. It contains a single $\mathrm{Sec}$ residue in the middle of the protein in a conserved Cys-Gly-Sec-Lys putative redox-active center [39]. The 15-kd protein does not share any sequence homology to previously characterized proteins and its function currently is not known. The 15-kd selenoprotein is expressed in a variety of tissues with increased levels in prostate and thyroid. It has been found in humans, mice and rats. C. elegans and Brugia malayi also contain homologs of this selenoprotein, but the homologs have cysteine in place of Sec.

Preliminary evidence suggests that the 15-kd selenoprotein may be involved in cancer [40]. Indeed, selenoprotein expression is altered in several tested cancers and two cancer-related polymorphisms have been found in the 3'-untranslated region of the human protein, including one in the SECIS element. These variations in sequence may potentially affect the expression level of the protein in malignant relative to normal tissue.

The 15 -kd protein has been isolated from rat prostate and mouse liver in a complex with UDP-glucose glycoprotein glucosyltransferase (UGTR) [40]. Interestingly, UGTR is involved in quality control of protein folding by glucosylating misfolded proteins and directing them for degradation. If indeed the $15-\mathrm{kd}$ protein is involved in this process, it will be an interesting new role for a selenoprotein.

\section{The Future: Role of Sec in Health and Total Number of Selenoproteins}

The role that selenium plays as an important component in the diet of mammals apparently changes with age. That is, selenium serves as an absolutely essential micronutrient in early mammalian development since removal of the Sec tRNA gene from the mouse genome is lethal to the embryo [15]. Furthermore, rats that are weaned at birth onto a selenium-deficient diet manifest dramatically slower rates of growth, abnormal muscle and skeletal development, develop cataracts and a variety of other disorders as compared to their siblings maintained on a selenium-sufficient diet. Adult rats and mice maintained on a selenium-deficient diet for extended periods of time appear to be less affected by the loss of selenium unless challenged by environmental stress. Although in studies involving selenium-deficient animals, selenoprotein expression has not been reduced as effectively as in Sec tRNA gene knockout studies, these nutritional experiments suggest that the role of selenium may change from an essential requirement to sustain life in embryonic development to one that is a requirement for adequate growth and development at birth to more of a chemopreventive or protective agent against environmental stress in later life. Studies involving conditional removal of the Sec tRNA gene from the genome of mice (i.e., conditional knockouts) at selected stages of development and in selected tissues $[5,77,79]$ should provide further insight into defining the role of selenium throughout life. Experiments in which mice are generated carrying the Sec tRNA gene so that the gene can be conditionally removed from the genome of mice are in progress [Hatfield, unpubl. data].

Selenium deficiency in humans is associated with numerous health disorders, including increased cancer risk, AIDS mortality, heart disease and problems with the male reproductive system $[23,63,69]$. This may be explained by the fact that selenium deficiency results in decreased selenoprotein expression and, hence, in the disruption of processes that are maintained by these selenoproteins. Supplementation of the human diet with selenium therefore offers a potentially efficient and inexpensive means of preventing or delaying the onset of certain of these maladies. Future research will, no doubt, result in determining the precise mechanisms of how selenium benefits human health and in offering this micronutrient as a dietary supplement to people at risk of developing various types of cancer, AIDS and other diseases that are influenced by selenium. Most certainly, many, if not all, of the beneficial effects of selenium on human health are mediated by selenoproteins, but which selenoproteins are involved and their role is not well understood. It is also quite likely that many protective effects of selenium are mediated by yet-to-be characterized selenoproteins.

The total number of selenoproteins that are encoded in the genomes of mammals is difficult to predict. Various estimates range from 25 to 100 . These estimates are based on ${ }^{75}$ Se-labeling experiments, which detect selenoprotein spots on $2 \mathrm{D}$ gels $[6,7]$, and on the extrapolation of the current proportion of known selenoproteins among all 
characterized proteins taking into account that many selenoproteins are expressed in low levels [Gladyshev, unpubl. data]. In fact, the growing interest in discovering novel selenoproteins is hampered in part by the difficulty involved in their identification due to low expression levels.

An important task in further developing the selenoprotein field and in elucidating the role of selenium in human health is the detection, isolation and characterization of additional selenoproteins. There are several approaches that may be used in identifying new selenoproteins. For example, isolation of labeled proteins from tissues and cells following labeling of animals and cell lines with ${ }^{75} \mathrm{Se}$. Historically, this has been the most productive approach in identifying new selenoproteins and it still proves to be a useful technique for this purpose. More recently, identification of Sec-encoded TGA codons and of SECIS elements followed by determination of the selenoprotein open reading frame in nucleotide databases has been very useful in finding novel selenoproteins. Searches of databases utilizing the unique features of the Sec insertion machinery have been aided tremendously by recent developments in projects involving sequencing of entire genomes, and by the expressed sequence tag projects. For example, the approach of identifying SECIS elements in nucleotide databases was recently applied to search for potential SECIS elements in the HIV genome [43, 92]. SECIS elements are characterized by the presence of a highly conserved ATGAN[10-12 nucleotides]AAN[1626 nucleotides] NGAN sequence, which forms stem-loop structures with AAN located in the loop, and TGAN and NGAN forming the non-Watson-Crick quartet interac- tion [66, 99]. Searching for SECIS elements in nucleotide databases is a unique tool for identifying new mammalian selenoproteins [Kryukov and Gladyshev, unpubl. data].

An alternative computer approach to search for novel selenoproteins involves an examination of nucleotide databases for Sec TGA codons. This approach takes advantage of the fact that many mammalian selenoproteins have homologs in lower eukaryotes, and these homologs incorporate cysteine in place of Sec. Thus, computer approaches may be utilized that search for in-frame TGA codons in the mammalian nucleotide sequences that correspond to TGC/T in lower organisms.

The above approaches of 'digital cloning' for discovering new selenoproteins are unlikely to result in the identification of all mammalian selenoprotein genes, but the development of these methods will be useful for future whole genome sequence analyses. Completion of the sequence of the human genome, which is scheduled to be finished in 2003 [100], as well as completion of the C. elegans and $D$. melanogaster genome projects will be invaluable in detecting all selenoprotein genes encoded in these genomes.

An additional area to be explored in the near future is high-throughput, comprehensive analysis of relative transcript expression levels [104]. The emerging technologies, such as serial analysis of gene expression, differential display approaches and various hybridization analyses (such as microchips and membranes) will not only reveal parallel changes in selenoprotein expression, but also determine how selenium affects expression of proteins that do not contain selenium.

\section{References}

1 Arner ES, Bjornstedt M, Holmgren A. 1Chloro-2,4-dinitrobenzene is an irreversible inhibitor of human thioredoxin reductase. Loss of thioredoxin disulfide reductase activity is accompanied by a large increase in NADPH oxidase activity. J Biol Chem 270:3479-3482; 1995.

2 Aumann KD, Bedorf N, Brigelius-Flohe R, Schomburg D, Flohe L. Glutathione peroxidase revisited - Simulation of the catalytic cycle by computer-assisted molecular modelling. Biomed Environ Sci 10:136-155;1997.

3 Baker A, Payne CM, Briehl MM, Powis G. Thioredoxin, a gene found overexpressed in human cancer, inhibits apoptosis in vitro and in vivo. Cancer Res 57:5162-5167;1997.
4 Beck MA, Esworthy RS, Ho YS, Chu FF. Glutathione peroxidase protects mice from viralinduced myocarditis. FASEB J 12:1143-1149; 1998.

5 Bedell MA, Jenkins NA, Copeland NG. Mouse models of human disease. Part I: Techniques and resources for genetic analysis in mice. Genes Dev 11:1-10;1997.

6 Behne D, Hilmert H, Scheid S, Gessner H, Elger W. Evidence for specific selenium target tissues and new biologically important selenoproteins. Biochim Biophys Acta 966:12-21;1988.

7 Behne D, Kyriakopoulos A, Weiss-Nowak C, Kalckloesch M, Westphal C, Gessner H. Newly found selenium-containing proteins in the tissues of the rat. Biol Trace Elem Res 55:99-110; 1996.
8 Beilstein MA, Vendeland SC, Barofsky E, Jensen ON, Whanger PD. Selenoprotein W of rat muscle binds glutathione and an unknown small molecular weight moiety. J Inorg Biochem 61:117-124;1996.

9 Berry MJ, Banu L, Chen YY, Mandel SJ, Kieffer JD, Harney JW, Larsen PR. Recognition of UGA as a selenocysteine codon in type I deiodinase requires sequences in the 3 ' untranslated region. Nature 353:273-276;1991.

10 Berry MJ, Banu L, Harney JW, Larsen PR. Functional characterization of the eukaryotic SECIS elements which direct selenocysteine insertion at UGA codons. EMBO J 12:3315$3322 ; 1993$. 
11 Bjornstedt M, Xue J, Huang W, Akesson B, Holmgren $A$. The thioredoxin and glutaredoxin systems are efficient electron donors to human plasma glutathione peroxidase. J Biol Chem 269:29382-29384;1994.

12 Bjornstedt M, Hamberg M, Kumar S, Xue J, Holmgren A. Human thioredoxin reductase directly reduces lipid hydroperoxides by NADPH and selenocystine strongly stimulates the reaction via catalytically generated selenols. J Biol Chem 270:11761-11764;1995.

13 Bjornstedt M, Kumar S, Holmgren A. Selenite and selenodiglutathione: Reactions with thioredoxin systems. Methods Enzymol 252:209219;1995.

14 Böck A. Incorporation of selenium into bacterial selenoprotein. In: (Burk RF, ed.) Selenium in Biology and Human Health. New York, Springer, 146-177;1994.

15 Bosl MR, Takaku K, Oshima M, Nishimura S, Taketo MM. Early embryonic lethality caused by targeted disruption of the mouse selenocysteine tRNA gene (Trsp). Proc Natl Acad Sci USA 94:5531-5534;1997.

16 Boyington JC, Gladyshev VN, Khangulov SV, Stadtman TC, Sun PD. Crystal structure of formate dehydrogenase $\mathrm{H}$ : Catalysis involving Mo, molybdopterin, selenocysteine, and an $\mathrm{Fe}_{4} \mathrm{~S}_{4}$ cluster. Science 275:1305-1308:1997.

17 Burk RF, Hill KE, Awad JA, Morrow JD, Kato T, Cockell KA, Lyons PR. Pathogenesis of diquat-induced liver necrosis in selenium-deficient rats: Assessment of the roles of lipid peroxidation and selenoprotein P. Hepatology 21:561-569;1995.

18 Chambers I, Frampton J, Goldfarb P, Affara $N$, McBain W, Harrison PR. The structure of the mouse glutathione peroxidase gene: The selenocysteine in the active site is encoded by the 'termination' codon, TGA. EMBO J 5: 1221-1227;1986.

19 Ching WM. Occurrence of selenium-containing tRNAs in mouse leukemia cells. Proc Natl Acad Sci USA 81:3010-3013;1984.

20 Ching WM, Tsai L, Wittwer AJ. Selenium-containing transfer RNAs. Curr Top Cell Regul 27: 497-507;1985.

21 Chittum HS, Himeno S, Hill KE, Burk RF. Multiple forms of selenoprotein $P$ in rat plas ma. Arch Biochem Biophys 325:124-128; 1996.

22 Chu FF, Esworthy RS, Ho YS, Bermeister M, Swiderek K, Elliott RW. Expression and chromosomal mapping of mouse Gpx2 gene encod. ing the gastrointestinal form of glutathione peroxidase, GPX-GI. Biomed Environ Sci 10 ; 156-162;1997.

23 Clark LC, Combs GF, Turnbull BW, Slate EH, Chalker DK, Chow J, Davis LS, Glover RA, Graham GF, Gross EG, Krongrad A, Lesher JL, Park HK, Sanders BB, Smith CL, Taylor JR. Effects of selenium supplementation for cancer prevention in patients with carcinoma of the skin. A randomized controlled trial. $\mathrm{Nu}$ tritional Prevention of Cancer Study Group. JAMA 276:1957-1963;1996.
24 Croteau W, Davey JC, Galton VA, St Germain DL. Cloning of the mammalian type II iodothyronine deiodinase. A selenoprotein differentially expressed and regulated in human and rat brain and other tissues. $\mathrm{J}$ Clin Invest 98 : 405-417;1996.

25 Deiss LP, Kimchi A. A genetic tool used to identify thioredoxin as a mediator of a growth inhibitory signal. Science 252:117-120;1991.

26 Dilworth GL. Properties of the selenium-containing moiety of nicotinic acid hydroxylase from Clostridium barkeri. Arch Biochem Biophys 219:30-38;1982.

27 Dilworth GL. Occurrence of molybdenum in the nicotinic acid hydroxylase from Clostridium barkeri. Arch Biochem Biophys 221:565$569 ; 1983$.

28 Engman L, Cotgreave I, Angulo M, Taylor CW, Paine-Murrieta GD, Powis G. Diaryl chalcogenides as selective inhibitors of thioredoxin reductase and potential antitumor agents. Anticancer Res 17:4599-4605;1997.

29 Epp O, Ladenstein R, Wendel A. The refined structure of the selenoenzyme glutathione peroxidase at $0.2 \mathrm{~nm}$ resolution. Eur $J$ Biochem 133:51-69;1983.

30 Esworthy RS, Baker MA, Chu FF. Expression of selenium-dependent glutathione peroxidase in human breast tumor cell lines. Cancer Res 55:957-962;1995.

31 Esworthy RS, Swiderek KM, Ho YS, Chu FF. Selenium-dependent glutathione peroxidaseGI is a major glutathione peroxidase activity in the mucosal epithelium of rodent intestine. Biochim Biophys Acta 1381:213-226;1998.

32 Evan $\mathrm{G}$, Littlewood T. A matter of life and cell death. Science 281:1317-1320;1998.

33 Gallegos A, Gasdaska JR, Taylor CW, PaineMurrieta GD, Goodman D, Gasdaska PY, Berggren M, Briehl MM, Powis G. Transfection with human thioredoxin increases cell proliferation and a dominant-negative mutant thioredoxin reverses the transformed phenotype of human breast cancer cells. Cancer Res 56:5765-5770;1996.

34 Gallegos A, Berggren M, Gasdaska JR, Powis G. Mechanisms of the regulation of thioredoxin reductase activity in cancer cells by the chemopreventive agent selenium. Cancer Res 57 : 4965-4970;1997

35 Gasdaska PY, Gasdaska JR, Cochran S, Powis G. Cloning and sequencing of a human thioredoxin reductase. FEBS Lett 373:5-9;1995.

36 Gladyshev VN, Khangulov SV, Stadtman TC Nicotinic acid hydroxylase from Clostridium barkeri: Electron paramagnetic resonance studies show that selenium is coordinated with molybdenum in the catalytically active seleniumdependent enzyme. Proc Natl Acad Sci USA $91: 232-236 ; 1994$

37 Gladyshev VN, Khangulov SV, Stadtman TC. Properties of the selenium- and molybdenumcontaining nicotinic acid hydroxylase from Clostridium barkeri. Biochemistry 35:212$223 ; 1996$.
38 Gladyshev VN, Jeang KT, Stadtman TC. Selenocysteine, identified as the penultimate $C$-terminal residue in human $T$-cell thioredoxin reductase, corresponds to TGA in the human placental gene. Proc Natl Acad Sci USA 93:6146$6151 ; 1996$.

39 Gladyshev VN, Jeang KT, Wootton JC, Hatfield DL. A new human selenium-containing protein. Purification, characterization, and cDNA sequence. J Biol Chem 273:8910-8915; 1998.

40 Gladyshev VN, Diamond AM, Factor VM, Wootton JC, Moustafa M, Jeang KT, Berry MJ, Parodi A, Lee BJ, Hatfield DL. Association between a novel mammalian $15 \mathrm{kDa}$ protein and cancer. FASEB J 12:A1431;1998.

41 Gladyshev VN, Factor VM, Housseau F, Hatfield DL. Contrasting patterns of regulation of the antioxidant selenoproteins, thioredoxin reductase and glutathione peroxidase, in cancer cells. Biochem Biophys Res Commun 251: 488-493;1998.

42 Gorlatov SN, Stadtman TC. Human thioredoxin reductase from HeLa cells: Selective alkylation of selenocysteine in the protein inhibits enzyme activity and reduction with NADPH influences affinity to heparin. Proc Natl Acad Sci USA 95:8520-8525;1998.

43 Grate L. Potential SECIS elements in HIV -1 strain HXB2. J Acquir Immune Defic Syndr Hum Retrovirol 17:398-403;1998.

44 Gromer S, Arscott LD, Williams CH Jr, Schirmer RH, Becker K. Human placenta thioredoxin reductase. Isolation of the selenoenzyme, steady state kinetics, and inhibition by therapeutic gold compounds. I Biol Chem 273:20096-20101;1998.

45 Guimaraes MJ, Peterson D, Vicari A, Cocks BG, Copeland NG, Gilbert DJ, Jenkins NA, Ferrick DA, Kastelein RA, Bazan JF, Zlotnik A. Identification of a novel selD homolog from eukaryotes, bacteria, and archaea: Is there an autoregulatory mechanism in selenocysteine metabolism? Proc Natl Acad Sci USA 93: 15086-15091;1996.

46 Hatfield DL, Diamond AM. UGA: A split personality in the universal genetic code. Trends Genet 9:69-70;1993

47 Hatfield DL, Choi IS, Ohama T, Jung JE, Diamond AM. Selenocysteine tRNA ${ }^{[S e r] S e c}$ isoacceptors as central components is selenoprotein biosynthesis in eukaryotes. In: Burk RH, ed. Selenium in Biology and Human Health. New York, Springer, 26-44;1994.

48 Hatfield DL, Gladyshev VN, Park J, Park SI, Chittum HS, Baek HJ, Carlson BA, Yang ES, Moustafa ME, Lee BJ. Biosynthesis of selenocysteine and its incorporation into protein as the 21 st amino acid. Compr Nat Prod Chem 4: 353-380;1999.

49 Heider J, Böck A. Selenium metabolism in microorganisms. Adv Microb Physiol 35:71109;1993.

50 Hill KE, Lloyd RS, Burk RF. Conserved nucleotide sequences in the open reading frame and 3 untranslated region of selenoprotein $P$ mRNA. Proc Natl Acad Sci USA 90:537-541; 1993. 
51 Hill KE, Burk RF. Selenoprotein P: Recent studies in rats and in humans. Biomed Environ Sci 10:198-208;1997.

52 Hill KE, McCollum GW, Boeglin ME, Burk RF. Thioredoxin reductase activity is decreased by selenium deficiency. Biochem Biophys Res Commun 234:293-295;1997.

53 Himeno S, Chittum HS, Burk RF. Isoforms of selenoprotein $\mathrm{P}$ in rat plasma. Evidence for a full-length form and another form that terminates at the second UGA in the open reading frame. J Biol Chem 271:15769-15775;1996.

54 Ho YS, Magnenat JL, Bronson RT, Cao J, Gargano $M$, Sugawara $M$, Funk $C D$. Mice deficient in cellular glutathione peroxidase develop normally and show no increased sensitivity to hyperoxia. J Biol Chem 272:16644-16651; 1997.

55 Hofman ER, Boyanapalli M, Lindner DJ, Weihua X, Hassel BA, Jagus R, Gutierrez PL, Kalvakolanu $D V$. Thioredoxin reductase mediates cell death effects of the combination of beta interferon and retinoic acid. Mol Cell Biol 18: 6493-6504; 1998.

56 Holmgren A. Bovine thioredoxin system. Purification of thioredoxin reductase from calf liver and thymus and studies of its function in disulfide reduction. J Biol Chem 252:4600-4606; 1977.

57 Khorana HG, Buchi H, Ghosh H, Gupta N, Jacob TM, Kossel H, Morgan R, Narang SA, Ohtsuka E, Wells RD. Polynucleotide synthesis and the genetic code. Cold Spring Harb Symp Quant Biol 31:39-49;1966.

58 Kim IY, Guimaraes MJ, Zlotnik A, Bazan JF, Stadtman TC. Fetal mouse selenophosphate synthetase 2 (SPS2): Characterization of the cysteine mutant form overproduced in a baculovirus-insect cell system. Proc Natl Acad Sci USA 94:418-421;1997.

59 Koishi R, Kawashima I, Yoshimura C, Sugawara $\mathrm{M}$, Serizawa $\mathrm{N}$. Cloning and characterization of a novel oxidoreductase KDRF from a human bone marrow-derived stromal cell line KM-102. J Biol Chem 272:2570-2577;1997.

60 Kunkel MW, Kirkpatrick DL, Johnson JI, Powis G. Cell line-directed screening assay for inhibitors of thioredoxin reductase signaling as potential anti-cancer drugs. Anticancer Drug Des 12:659-670;1997.

61 Liu SY, Stadtman TC. Heparin-binding properties of selenium-containing thioredoxin reductase from $\mathrm{HeLa}$ cells and human lung adenocarcinoma cells. Proc Natl Acad Sci USA 94: 6138-6141;1997.

62 Larsen PR. Update on the human iodothyronine selenodeiodinases, the enzymes regulating the activation and inactivation of thyroid hormone. Biochem Soc Trans 25:588-592;1997.

63 Lee BJ, Park SI, Park JM, Chittum HS, Hatfield DL. Molecular biology of selenium and its role in human health. Mol Cells 6:509-520; 1996.

64 Leinfelder W, Zehelein E, Mandrand-Berthelot MA, Bock A. Gene for a novel tRNA species that accepts L-serine and cotranslationally inserts selenocysteine. Nature 331:723-725; 1988.
65 Low SC, Harney JW, Berry MJ. Cloning and functional characterization of human selenophosphate synthetase, an essential component of selenoprotein synthesis. J Biol Chem 270: 21659-21664;1995.

66 Low SC, Berry MJ. Knowing when not to stop: Selenocysteine incorporation in eukaryotes. Trends Biochem Sci 21:203-208;1996.

67 Lundstrom J, Holmgren A. Protein disulfideisomerase is a substrate for thioredoxin reductase and has thioredoxin-like activity. J Biol Chem 265:9114-9120;1990.

68 Lundstrom-Ljung J, Birnbach U, Rupp K, Soling HD, Holmgren A. Two resident ER-proteins, $\mathrm{CaBP} 1$ and $\mathrm{CaBP} 2$, with thioredoxin domains, are substrates for thioredoxin reductase: Comparison with protein disulfide isomerase. FEBS Lett 357:305-308;1995.

69 Maiorino M, Wissing JB, Brigelius-Flohe $R$, Calabrese F, Roveri A, Steinert P, Ursini F, Flohe L. Testosterone mediates expression of the selenoprotein PHGPx by induction of spermatogenesis and not by direct transcriptional gene activation. FASEB J 12:1359-1370;1998.

70 Marshall RE, Caskey CT, Nirenberg M. Fine structure of RNA codewords recognized by bacterial, amphibian, and mammalian transfer RNA. Science 155:820-826;1967.

71 Mau BL, Powis G. Inhibition of thioredoxin reductase (E.C. 1.6.4.5.) by antitumor quinones. Free Radic Res Commun 8:365-372; 1990.

72 Mau BL, Powis G. Inhibition of cellular thioredoxin reductase by diaziquone and doxorubicin. Relationship to the inhibition of cell proliferation and decreased ribonucleotide reductase activity. Biochem Pharmacol 43:1621-1627; 1992.

73 May JM, Mendiratta S, Hill KE, Burk RF. Reduction of dehydroascorbate to ascorbate by the selenoenzyme thioredoxin reductase. J Biol Chem 272:22607-22610;1997.

74 May JM, Cobb CE, Mendiratta S, Hill KE, Burk RF. Reduction of the ascorbyl free radical to ascorbate by thioredoxin reductase. J Biol Chem 273:23039-23045; 1998 .

75 Nirenberg M, Caskey T, Marshall R, Brimacombe R, Kellogg D, Doctor B, Hatfield D, Levin J, Rottman F, Pestka S, Wilcox M, Anderson $F$. The RNA code and protein synthesis. Cold Spring Harb Symp Quant Biol 31:11-24; 1966.

76 Nordberg J, Zhong L, Holmgren A, Arner ES. Mammalian thioredoxin reductase is irreversibly inhibited by dinitrohalobenzenes by alkylation of both the redox active selenocysteine and its neighboring cysteine residue. $J$ Biol Chem 273:10835-10842;1998.

77 Porter A. Controlling your losses: Conditional gene silencing in mammals. Trends Genet 14: 73-79;1998.

78 Pushpa-Rekha TR, Burdsall AL, Oleksa LM, Chisolm GM, Driscoll DM. Rat phospholipidhydroperoxide glutathione peroxidase. CDNA cloning and identification of multiple transcription and translation start sites. J Biol Chem 270:26993-26999;1995.
79 Rajewsky K, Gu H, Kuhn R, Betz UA, Muller W, Roes J, Schwenk F. Conditional gene targeting. J Clin Invest 98:600-603;1996.

80 Read R, Bellew T, Yang JG, Hill KE, Palmer IS, Burk RF. Selenium and amino acid composition of selenoprotein $P$, the major selenoprotein in rat serum. $J$ Biol Chem 265:17899$17905 ; 1990$.

81 Ren B, Huang W, Akesson B, Ladenstein R. The crystal structure of selenoglutathione peroxidase from human plasma at $2.9 \AA$ resolution. J Mol Biol 268:869-885; 1997.

82 Rigobello MP, Callegaro MT, Barzon E, Benetti M, Bindoli A. Purification of mitochondrial thioredoxin reductase and its involvement in the redox regulation of membrane permeability. Free Radic Biol Med 24:370-376;1998.

83 Rozell B, Hansson HA, Luthman M, Holmgren A. Immunohistochemical localization of thioredoxin and thioredoxin reductase in adult rats. Eur J Cell Biol 38:79-86;1985.

84 Rubartelli A, Bonifaci N, Sitia R. High rates of thioredoxin secretion correlate with growth arrest in hepatoma cells. Cancer Res 55:675-680; 1995.

85 Salvatore D, Bartha T, Harney JW, Larsen PR. Molecular biological and biochemical characterization of the human type 2 selenodeiodinase. Endocrinology 137:3308-3315;1996.

86 Stadtman TC. Selenocysteine. Annu Rev Biochem $65: 83-100 ; 1996$

87 Sun QA, Wu YL, Zappacosta F, Jeang KT, Lee BJ, Hatfield DL, Gladyshev VN. Submitted.

88 Sunde RA. Intracellular glutathione peroxidases - Structure, regulation, and function. In: (Burk RF, ed.) Selenium in Biology and Human Health. New York, Springer, 146-177; 1994.

89 Sunde RA, Thompson BM, Palm MD, Weiss SL, Thompson KM, Evenson JK. Selenium regulation of selenium-dependent glutathione peroxidases in animals and transfected $\mathrm{CHO}$ cells. Biomed Environ Sci 10:346-355;1997.

90 Tagaya $X$, Maeda $Y$, Mitsui A, Kondo N, Matsui H, Hamuro J, Brown N, Akai K, Yokota T, Wakasugi $\mathrm{H}$, et al. ATL-derived factor (ADF) an IL-2 receptor/Tac inducer homologous to thioredoxin; possible involvement of dithiolreduction in the $\mathrm{IL}-2$ receptor induction. EMBO J 8:757-764;1989.

91 Tamura T, Stadtman TC. A new selenoprotein from human lung adenocarcinoma cells: Purification, properties, and thioredoxin reductase activity. Proc Natl Acad Sci USA 93:1006$1011 ; 1996$.

92 Taylor EW, Ramanathan CS, Jalluri RK, Nadimpalli RG. A basis for new approaches to the chemotherapy of AIDS: Novel genes in HIV-1 potentially encode selenoproteins expressed by ribosomal frameshifting and termination suppression. J Med Chem 37:2637-2654;1994.

93 Ursini F, Maiorino M, Roveri A. Phospholipid hydroperoxide glutathione peroxidase (PHGPx): More than an antioxidant enzyme? Biomed Environ Sci 10:327-332;1997.

94 Ursini F, Maiorino M, Brigelius-Flohe R, Aumann KD, Roveri A, Schomburg D, Flohe L. Diversity of glutathione peroxidases. Methods Enzymol 252:38-53;1995. 
95 U-Taniguchi Y, Furuke K, Masutani H, Nakamura $\mathbf{H}$, Yodoi J. Cell cycle inhibition of HTLV-I transformed T cell lines by retinoic acid: The possible therapeutic use of thioredoxin reductase inhibitors. Oncol Res 7:183-189; 1995.

96 Vendeland SC, Beilstein MA, Chen CL, Jensen ON, Barofsky E, Whanger PD. Purification and properties of selenoprotein $\mathrm{W}$ from rat muscle. J Biol Chem 268:17103-17107;1993.

97 Vendeland SC, Beilstein MA, Yeh JY, Ream W, Whanger PD. Rat skeletal muscle selenoprotein W: cDNA clone and mRNA modulation by dietary selenium. Proc Natl Acad Sci USA 92:8749-8753;1995.
98 Veres Z, Stadtman TC. A purified selenophosphate-dependent enzyme from Salmonella typhimurium catalyzes the replacement of sulfur in 2-thiouridine residues in tRNAs with selenium. Proc Natl Acad Sci USA 91: 8092-8096;1994.

99 Walczak R, Hubert N, Carbon P, Krol A. A novel RNA structural motif in the selenocysteine insertion element of eukaryotic selenoprotein mRNAs. RNA 2:367-379;1996.

100 Waterston R, Sulston JE. The Human Genome Project: Reaching the finish line. Science 282:53-54;1998.

101 Yeh JY, Vendeland SC, Gu Q, Butler JA, Ou $B R$, Whanger $P D$. Dietary selenium increases selenoprotein W levels in rat tissues. J Nutr 127:2165-2172;1997.
102 Zhong $\mathrm{L}$, Arner ES, Ljung $J$, Aslund $F$, Holmgren A. Rat and calf thioredoxin reductase are homologous to glutathione reductase with a carboxyl-terminal elongation containing a conserved catalytically active penultimate selenocysteine residue. $\mathrm{J}$ Biol Chem 273:8581-8591;1998.

103 Zinoni F, Birkmann A, Stadtman TC, Böck A. Nucleotide sequence and expression of the selenocysteine-containing polypeptide of formate dehydrogenase (formate-hydrogenlyase-linked) from Escherichia coli. Proc Nat1 Acad Sci USA 83:4650-4654;1986.

$104 \mathrm{http} / /$ www.ncbi.nlm.nih.gov/ncicgap/expression_tech_info.html, 11/06/98. 